\title{
Redesigning U.S. Intercollegiate Athletics to Better Conform with UNESCO's Best Practices in Student Affairs
}

\begin{abstract}
Marc Edelman*
This paper calls for the massive redesign of intercollegiate athletics departments in the United States (U.S.) in light of their widespread and fundamental failure to serve a bona fide student affairs mission, and their prevalent practice of placing the college's commercial motives above the financial and educational needs of studentathletes. The first section of this paper discusses the general purpose and functions of student affairs departments within the broader context of higher education. The next two sections of this paper then explore the shortcomings of U.S. intercollegiate athletics departments to conform to these general purposes and functions. Finally, this paper proposes a bifurcated solution to reform U.S. intercollegiate athletics, which enables a small number of U.S. colleges to shift toward a true commercial sports business model, with the overwhelming majority of U.S. colleges, by contrast, adopting a true, non-commercial sports model.
\end{abstract}

Keywords: intercollegiate athletics, student affairs, student-athlete, higher education, commercial sports

\section{Introduction}

The general mission of student affairs departments in higher education is to support the learning, development, and success of students. However, intercollegiate athletics departments in the United States (U.S.) operate as an aberration, anomaly, and exception within the broader world of student affairs. Whereas most U.S. student affairs departments aim to facilitate students' academic and personal success, many U.S. intercollegiate athletics departments strive to create a broader sense of institutional pride through the achievement of on-field wins and team championships. ${ }^{1}$

While it may be possible, in theory, to reconcile the goals of U.S. intercollegiate athletics with the broader mission of student-affairs, the current model of collegiate sports, as adopted by most U.S. universities, fails to align itself with the broader principles about how student affairs departments should operate. Rather

\footnotetext{
* Marc Edelman, JD, is a professor of law at the Zicklin School of Business, Baruch College, City University of New York; email: marcedelman@aol.com.

${ }^{1}$ Donald G. DiPaolo, Leadership Education Is not Enough: Advancing an Integrated Model of Student-Athlete Development, 16 J. Educ. LeAdership 216, 225 (2017).
} 
than focusing on the academic and personal growth of student-athletes, the athletic departments at many U.S. colleges instead transform their student-athletes into unwitting and unpaid employees. ${ }^{2}$ This violates the very basic principle to do more good than harm.

The problems resulting from the National Collegiate Athletic Association's (NCAA) model for intercollegiate athletics, however, may go ignored by intercollegiate sport organizations in other countries that look to replicate the NCAA's commercial success in the U.S. For instance, NCAA president Mark Emmert visited Tokyo, Japan, on August 31, 2017, to discuss the creation of a Japanese version of the NCAA. ${ }^{3}$ On his visit to Japan, Emmert addressed the emergence of a global interest in the NCAA's model by stating that, "[t]he rest of the world is looking to do what we do." Instead of selling its controversial model for intercollegiate athletics to other countries, perhaps it's time for the NCAA to adopt a more internationally accepted understanding of how student-athletes should be treated by their institutions of higher learning.

This paper calls for the massive redesign of U.S. intercollegiate athletics departments in light of their widespread and fundamental failure to serve a bona fide student affairs mission. Part I of this article discusses the general purpose of student affairs departments within the broader context of higher education, and it begins to explore the view of the United Nations Educational, Scientific and Cultural Organization (UNESCO) about how collegiate athletics should fit within the general framework of student affairs. ${ }^{5}$ Part II analyzes the success (or lack thereof) of the U.S. version of college athletics under UNESCO's general principles for evaluating student affairs departments. Part III evaluates U.S. collegiate athletics departments based on UNESCO sports-specific criteria. Finally, Part IV proposes a reasonable means to reform intercollege sports in the United States. Specifically, the proposal calls for a bifurcated reform of collegiate sports in the U.S., with a small number of revenue-generating colleges, in a small number of sports, adopting a commercial sports business model, and the overwhelming remainder of colleges adopting a non-commercial model that conforms to the principles of student affairs advocated by UNESCO.

\footnotetext{
2 Marc Edelman, From Student-Athletes to Employee-Athletes: Why a 'Pay for Play' Model of College Sports Would not Necessarily Make Educational Scholarships Taxable, 58 B.C. L. REV. 1137, 1141-43 (2017).

3 Zach Schonbrun, An N.C.A.A. for Japan? Emmert Heads Abroad, Offering Advice, N.Y. Times, Aug. 28, 2017, at B9, https://www.nytimes.com/2017/08/28/sports/ncaa-japan-mark-emmert-college-sports.html

${ }^{4}$ Id. at para. 20.

${ }^{5}$ UNESCO is a deservedly criticized organization based upon its controversial and inappropriate stance on Israel and its strongly anti-Zionist agenda. Nevertheless, this entirely justified criticism of UNESCO does not implicate the association's status as a primary source of world leadership on many issues, including the role of athletics in the university setting. While the organization's politics are, without question, troubling, for purposes of this paper they must be divorced from the association's broader mission and competence.
} 


\section{The General Purpose of Student Affairs}

Within U.S. higher education, student affairs departments serve a wide range of functions related to helping students to develop holistically. As Dallas Long explains in his article, "The Foundation of Student Affairs," student affairs departments are intended to facilitate students' learning by interweaving realworld learning opportunities "throughout the students' college experience." Although college professors serve as the experts with regards to teaching substantive material, student affairs employees help to bridge the gaps between classroom learning and real life.

The underlying purpose of student affairs departments, as articulated by Long, is consistent with best practices for student affairs set forth on an international level by UNESCO: an educational, science, and cultural organization that is composed of 205 separate member states including the United States. ${ }^{7}$ Indeed, the UNESCO manual proposes that "for any part of the higher education enterprise to be of top quality and to be consistently applied, it must be founded on a set of principles and values that take into consideration the expressed needs and choices of its clients (the primary clients are students)." 8

Moreover, the UNESCO manual sets forth several best practices that UES$\mathrm{CO}$ members believe that all student affairs departments, across all colleges, should adopt. One of these best practices is that "[s]tudent affairs and services must be delivered in a manner that is seamless, meaningful, and integrated with the academic mission of the institution." Another best practice is that "[h]igher education must address the personal and developmental needs of the student as a human being." 10 Meanwhile, a third best practice is that "[a]1l higher education stakeholders must promote independent, self-directed student behavior."11

With regards to college athletics as a type of student affairs, the UNESCO manual describes eight purposes/functions for these activities. These eight purposes/functions include the following:

- developing sports, recreational, and intramural programs based on "a student-centered philosophy emphasizing the overall quality of life;"

- conducting sports programs that foster academic success;

- providing a diversity of recreational sports;

- coordinating the use of campus recreational facilities with various units including physical education;

\footnotetext{
${ }^{6}$ Dallas Long, The Foundations of Student Affairs: A Guide to the Profession, in Environments for Student Growth and Development: Librarians and Student Affairs in Collaboration 1-39, at 1 (L.J. Hinchliffe \& M.A. Wong eds., 2012).

7 UNESCO, The Role of Student Affairs and Services in Higher Education (2002), http://unesdoc. unesco.org/images/0012/001281/128118e.pdf

8 Id. at 11 .

9 Id.

${ }_{10} I d$. at 12 .

${ }^{11} I d$.
} 
- providing extracurricular education through participation and leadership opportunities;

- contributing positively to institutional public relations;

- cooperating with academic units on laboratory exercises related to sport; and

- promoting physical fitness, skill development, productive hobbies, and conditioning. ${ }^{12}$

Combined, these eight purposes/functions present a coordinated vision of collegiate sports that is easily reconcilable with student affairs more generally under both the UNESCO and Long models.

\section{Assessing U.S. College Athletics Under UNESCO Principles for Student Affairs}

Although the UNESCO manual describes collegiate sports as inextricably linked with broader student affairs initiatives,$^{13}$ the intercollegiate athletics departments at most U.S. colleges do not operate like traditional student affairs departments, nor do they seem to adopt the more mainstream missions of U.S. student affairs in general. Indeed, even though U.S. college athletics departments first emerged around the same time as other student affairs departments, the enacted practices of U.S. intercollegiate athletics are historically disparate from those of all other areas of student affairs. For example, college athletics departments have emphasized succeeding on the field and financially rather than in terms of students' academic and personal development. ${ }^{14}$

When considering broadly UNESCO's best practices, there is undoubtedly disconnect between these principles and how college athletics departments operate in the U.S. For example, unlike most student affairs departments, U.S. college athletics departments are not "integrated with the academic mission of the university." 15 While the core academic mission of colleges is to educate students through classroom learning and a variety of related experiences, most college athletics departments regularly schedule games in a way that makes students miss substantial amounts of classroom time and other learning opportunities, leading to student-athletes' ongoing physical and mental fatigue. ${ }^{16}$ In addition, many college athletes feel pressured by their athletics departments to select majors that are less rigorous or fit better with their sports schedule rather than

\footnotetext{
12 Id. at 45 .

13 Id. at 22.

14 Eddie Comeaux \& C. Keith Harrison, A Conceptual Model of Academic Success for Student-Athletes, 40 Educ. Res. 235, 236 (2011).

15 UNESCO, supra note 6, at 11.

${ }^{16}$ Comeaux \& Harrison, supra note 13, at 235.
} 
those based on personal interest. ${ }^{17}$ Based on the foregoing, student-athletes, at least at the Division I level, experience a lower level of classroom success than non-athletes. ${ }^{18}$

In addition to a lack of integration of U.S. athletics departments with the broader college mission, many U.S. athletics departments fail to "address the personal and developmental needs of the student as a human being."19 Given that many U.S. college athletic directors approve of team schedules that require student-athletes to miss extensive class time, many student-athletes become isolated from other students on campus. ${ }^{20}$ Perhaps as a result of this social isolation, a disproportionately high number of U.S. college athletes suffer from depression and drug abuse. ${ }^{21}$

Finally, most college athletics departments also fail to "promote independent, self-directed student behavior." 22 Although most student affairs departments help students to gain skills about independent decision making, many athletics departments actually stymie independent student thinking by controlling even the minutiae of college athletes' day-to-day behavior. For example, at Northwestern University, college coaches determine the attire of the school's football players when traveling to road games, as well as what cars the players may drive while on campus, whether the players may seek outside employment, and even what content the players may post on the Internet. ${ }^{23}$ By denying student-athletes even the simple freedom to choose what messages to post on their own social media pages, college athletics departments at schools such as Northwestern University, in certain respects, keep their student-athletes entrenched in a child-like state.

\section{Assessing U.S. College Athletics Under UNESCO Athletics-Specific Principles}

Much as the current model for U.S. college sports fails to comport with UNESCO's general best practices for student affairs, it also, more specifically, fails to comport with the eight sports-specific purposes/functions described by the UNESCO manual. First, the UNESCO manual suggests that colleges should offer their recreational and intramural sports programs based on "a student-

\footnotetext{
17 Nw. U. \& C. Athletes Players Ass'n., Decision and Direction of Elections, Case No. 13-RC121359 (N.L.R.B. 13th Region Mar. 26, 2014) at 16-17, http://apps.nlrb.gov/link/document.aspx 109031d4581667b6f; overruled by Nw. U. \& C. Athletes Players Ass'n., Decision on Review and Order, Case No. 13-RC-121359 (N.L.R.B. August 17, 2015), http://apps.nlrb.gov/link/document. aspx/09031d4581d7160d

${ }^{18}$ Comeaux \& Harrison, supra note 13, at 235; Elisia J.P. Gatmen, Academic Exploitation: The Adverse Impact of College Athletics on the Educational Success of Minority Student-Athletes, 10 Seattle J. Soc. Just. 509 (2011).

19 UNESCO, supra note 6, at 12.

${ }^{20}$ Comeaux \& Harrison, supra note 13, at 236.

${ }^{21}$ DiPaolo, supra note 1 , at 218.

22 UNESCO, supra note 6, at 12.

${ }^{23}$ Nw. U. \& C. Athletes Players Ass'n., at 16 (N.L.R.B. 13th Region, 2014).
} 
centered philosophy emphasizing the overall quality of life." 24 This suggestion, however, fundamentally differs from the way most college sports operate in the U.S. For example, most U.S. athletics departments focus on providing highlevel competitive athletic opportunities to a few elite student-athletes rather than mainstream, athletic opportunities for the student masses. ${ }^{25}$ In addition, the U.S. college sports model is not truly "student-centered" given that the entire system is controlled and revenues (if any) are kept by the college and its employees. Further, it similarly would be improper to argue that intercollegiate sports in the U.S. emphasize "the overall quality of life" of the college athlete. ${ }^{26}$ If the quality of life of college athletes was prioritized, the athletes would play fewer games, engage in less travel, enjoy a better work-life balance, enjoy more free time, and participate in sports in a way that augments their role as students on campus, rather than isolates them from the general student body. ${ }^{27}$

Second, while the UNESCO model suggests that student affairs departments should "foster academic success," many contemporary U.S. athletics departments actually inhibit student success. ${ }^{28}$ Missed class days, less study time, and difficulty completing the necessary coursework for certain majors all make it less likely that some college athletes will excel in their studies under the current system of intercollegiate sports. ${ }^{29}$ These challenges are further exacerbated by the fact many schools admit student-athletes with lower high school GPAs and SAT scores than the overall student body, thus creating the perverse scenario where the very same students who are most likely to need additional study time to excel in the classroom are the same ones with additional opportunities that limit their class time. ${ }^{30}$

Although some college athletic departments will claim that they are able to compensate for student-athletes' missed class time by providing them with tutoring service while on the road, the recent practice of U.S. colleges to provide travel tutors does not fully compensate student-athletes for their missed class time. First, these travel tutors typically lack the same level in any given field as the college's professors. Second, even to the extent that a specific travel tutor has adequate substantive knowledge of a field or discipline, a one-on-one or small group tutoring session inevitably lacks the level of interactive debate and exchange of ideas that students experience when placed into the traditional classroom environment.

\footnotetext{
${ }^{24}$ UNESCO, supra note 6, at 45.

${ }^{25}$ National Collegiate Athletic Association, Estimated Probability of Competing in College Athletics (April 20, 2018), http://www.ncaa.org/about/resources/research/estimated-probability-competing-college-athletics

${ }^{26}$ UNESCO, supra note 6, at 45.

27 Comeaux \& Harrison, supra note 13, at 235.

28 UNESCO, supra note 6, at 45.

29 Jake New, A Competitive Disadvantage, Inside Higher Ed. (November 19, 2014), https://www. insidehighered.com/news/2014/11/19/are-selective-colleges-big-time-sports-greater-risk-compro$\underline{\text { mising-academics }}$

30 Sara Ganim, CNN Analysis: Some College Athletes Play Like Adults, Read Like Fifth Graders, CNN (Jan. 8, 2014), http://www.cnn.com/2014/01/07/us/ncaa-athletes-reading-scores/
} 
Third, with respect to the UNESCO goal of providing students with a diversity of recreational sports, on the one hand the current system of U.S. collegiate sports performs quite well. Under the National Collegiate Athletic Association (NCAA) bylaws, each member college must offer intercollegiate teams in at least 10 different sports. Because NCAA membership is nearly essential for offering intercollegiate athletics in the United States, this rule helps to ensure a wide diversity of sports opportunities. Nevertheless, on the other hand, many colleges focus mostly, if not entirely, on their organized sports opportunities to students that compete in intercollegiate athletics. For those students who lack the ability to compete on that level, the diversity of recreational sports offered may be quite limited.

Fourth, many college athletics departments do not coordinate the use of campus recreational facilities with various other college units including physical education. Rather, at the most highly commercialized sector of intercollegiate athletics, the university's sports teams participate in luxurious, off-campus sports facilities. By contrast, gym classes and intramural sports often compete in secondary facilities. Furthermore, at least at the Division I level, intercollegiate athletes generally enjoy exclusive access to an "athletes only" weight room and fitness facility, which typically offers higher-level equipment and less members per piece of equipment to the general student body's fitness facilities.

Fifth, U.S. intercollegiate athletics do not meet the UNESCO goal of "providing extracurricular education through participation and leadership opportunities." ${ }^{11}$ While "participation" is not the issue with intercollegiate athletics, the "leadership" component is troublesome. Whereas most collegiate extracurricular activities are student-run and operated, the oversight of intercollegiate sports was taken out of the hands of the student-athletes and given to college administrators around the turn of the 20th century. ${ }^{32}$ Paid college employees not only determine the macro-issues of U.S. intercollegiate sports such as conference affiliations and schedules, but they also serve as the coaches: setting practice schedules, starting lineups, and determining game plays. In addition, as mentioned in a previous section, the college-employed coaches even take over leadership tasks on the most micro level, such as how the team dresses on game day and the time of the team's curfew. While most college sports teams have team "captains" who are students, the role of these captains is often ceremonial and quite limited. Captains may lead certain drills in practice and call heads or tails in a coin flip, but they are not strategizing, organizing, choosing plays, or doing many of the other behaviors that would typically constitute sports "leadership."

Sixth, intercollegiate sports contribute both positively and negatively to institutional public relations. On the positive side, strong performance in college sports positively increases the brand recognition for many colleges. Indeed, without sport, few potential consumers would know about colleges such as Gonzaga University and Boise State University. But, on the negative side, the contemporary system of college sports has also led to some very serious, negative criticism in recent years about higher education in general. Not only are NCAA member

\footnotetext{
${ }^{31}$ UNESCO, supra note 6, at 45.

${ }^{32}$ Marc Edelman, The NCAA's 'Death Penalty' Sanction-Reasonable Self-Governance or Illegal Group Boycott in Disguise? 18 LewIS \& Clark L. Rev. 385, 389 (2014).
} 
colleges embroiled in numerous lawsuits related to athlete no-pay rules and concussions, ${ }^{33}$ but also renowned civil rights journalists such as Taylor Branch have described the current system of NCAA athletics, which prevent primarily young, poor and African-American football and men's basketball players from sharing in the wealth, as having an "unmistakable whiff of the plantation." 34

Seventh, UNESCO suggests intercollegiate sports should "cooperat[e] with academic units on laboratory exercises related to sport." ${ }^{35}$ Under the U.S. model of intercollegiate sports, there is essentially no cooperation between the academic units on campus and the athletic departments. Students do not earn academic credit for their involvement in intercollegiate sports, and the NCAA-created position of Faculty Athletics Representative is intended to serve as the conduit between the athletic department and academic personnel, thus limiting the direct contact between the leadership of the two groups. In addition, college athletic departments typically hire trainers and strength and conditioning coaches who are otherwise unaffiliated with the faculty at large. To the extent that academic and athletic units of a university work in tandem, that represents the exception rather than the rule.

Finally, with respect to the final UNESCO goal of "promoting physical fitness, skill development, productive hobbies, and conditioning," U.S. intercollegiate sports actually preform quite well. ${ }^{36}$ Nevertheless, it is only a small segment of the student community at most colleges that have the opportunity to compete in college sports. One might reasonably argue that building a few large, state-of-the-art fitness facilities around campus and providing all college students with free membership would do more to promote "physical fitness, skill development, productive hobbies, and conditioning" on college campuses than the current model of U.S. intercollegiate sports that provides excellent service in this area to a select few, whereas, on many campuses, the rest of the student body is left with few fitness opportunities.

\section{Reforming U.S. College Athletics to Better Align with the Student Affairs Mission}

Given the iconoclastic nature of big-time college sports at certain colleges in the United States, any meaningful effort to reform college athletics needs to adopt a bifurcated approach - separating college sports into two general classes of schools, with two very different college athletics frameworks. For the approximately $75-$ 125 colleges in the United States that already operate revenue-generating football and men's basketball programs, these colleges should designate their football and men's basketball players as "employees" who provide an important core function to the marketing and brand equity of the college. As such, these colleges should

\footnotetext{
${ }_{33}$ Jon Solomon, NCAA's Next Big Lawsuit over Scholarships Comes into Focus, CBS SpoRTs (July 11, 2014), http://www.cbssports.com/college-football/news/ncaas-next-big-lawsuit-over-scholarships-comes-into-focus

${ }^{34}$ Taylor Branch, The Shame of College Sports, AtLantic, October 2011, at 81.

${ }^{35}$ UNESCO, supra note 6, at 45.

${ }^{36} \mathrm{Id}$.
} 
voluntarily afford these athletes all the rights and responsibilities of employees, including a free-market salary. By contrast, for the upwards of 900 other college athletics departments in the U.S., the prudent course of action would be to forgo both the commercialization and the autonomous nature of their college athletics departments, and re-envision college athletics in a manner more consistent with the UNESCO principles and the broader principles of student affairs.

\section{The Employee-Athlete Model of College Sports}

The employee-athlete model of college sports recognizes that for a limited number of sports teams at a limited number of colleges, the purpose of certain athletics deviate so far from the UNESCO model of college sports that it would be disingenuous to even attempt to reorganize the way these teams operate to better conform to the UNESCO model. Rather than attempt to fit a proverbial square peg into a round hole, colleges should recognize that the big-time college athletes at these schools serve as "employees" based on their revenue-generating capacity - either directly through the team's ticket sales and media rights deals, or indirectly by helping to market the brand name of the school. Consequently, these athletes should receive some financial compensation for their work product, much as how college employees who develop a patentable technology typically share the derived revenues with their college.

Although there is no absolute criteria to determine which college sports programs should fall under the "employee-athlete" model, at a minimum, colleges that compete in NCAA Football Bowl Subdivision ("FBS") and NCAA Division I men's basketball should voluntarily adopt the employee-athlete model. This is because a regional director for the National Labor Relations Board has already concluded that the FBS football players at one private Big Ten college constitute "employees," ${ }^{37}$ and a recent federal court decision rejected the NCAA's argument that amateurism serves as a defense to not recognizing college athletes' commercial rights. ${ }^{38}$

Moreover, moving to an employee-athlete model also comports with an already existing and reasonable framework that colleges recognize with respect to their students who serve as dining coordinators, research assistants, residence hall advisors, teaching assistants, and even as employees in the public relations departments and athletic departments. Thus, recognizing the existence of an employer-employee relationship with certain college athletes is not as foreign of a principle as one may suggest.

\footnotetext{
${ }^{37}$ Nw. U. \& C. Athletes Players Ass'n., Decision and Direction of Elections, Case No. 13RC-121359 (N.L.R.B. 13th Region Mar. 26, 2014), http://apps.nlrb.gov/link/document.aspx /09031d4581667b6f; overruled on other grounds by Nw. U. \& C. Athletes Players Ass'n., Decision on Review and Order, Case No. 13-RC-121359 (N.L.R.B. August 17, 2015), http://apps.nlrb.gov/ link/document.aspx/09031d4581d7160d; more recently, a district court denied an NCAA's motion to dismiss in Livers v. NCAA and in doing so compared NCAA athletes to work-study employees. Memorandum RE: Motion to Dismiss Amended Complaint, CV No. 17-4271, https://dlbjbjzgnk95t.cloudfront.net/1067000/1067378/https-ecf-paed-uscourts-gov-doc1-153117260299.pdf ${ }^{38}$ O'Bannon v. Nat'l. Coll. Athletic Ass'n., 802 F.3d 1049 (9th Cir. 2015).
} 
Furthermore, even in the event that certain college athletes elect to unionize, this still would not represent a monumental shift to the existing labor relations between colleges and student workers. Indeed, as one recent National Labor Relations Board decision outside of the realm of college athletics has recognized, undergraduate college students have the legal right to unionize for purposes of bargaining over their hours, wages, and working conditions. ${ }^{39}$

\section{The Athletics Department as Student Affairs Model of College Sports}

Meanwhile, for the overwhelming majority of college sports teams that do not generate meaningful direct or indirect revenues from their collegiate sports teams, it would be reasonable for these schools to maintain the traditional "student" relationship with college athletes, but to move closer to following the UNESCO model of college sports. There are a number of ways that non-revenue college sports programs could better follow the spirit of the UNESCO model and move closer toward a student affairs model. First, these colleges should ensure that their athletics departments have a developed understanding about the broader discipline of higher education. This may be accomplished, in part, by hiring athletics personnel with appropriate educational backgrounds. For example, if a college requires the heads of its other student affairs departments to earn either an $\mathrm{EdD}$ or $\mathrm{PhD}$ in a related field, that same college should also require its athletic director candidates to earn a doctorate degree. By doing so, it increases the likelihood that at least the leader of the college's athletics department will be versed in the academic literature related to student success, especially in terms of contemporary educational and developmental theories. ${ }^{40}$

Modern colleges also should evaluate and compensate their athletics department members based on their attention to student-athletes' holistic learning experience. ${ }^{41}$ For example, a college coach who recruits a team that graduates with a high grade point average (GPA), high job placement, high intellectual curiosity, and strong leadership skills should receive a strong performance evaluation irrespective of the team's on-field wins and losses. By contrast, a coach who leads a team with low grades, poor job placement, and lack of intellectual curiosity should receive a poor job evaluation, even if the coach's team yields a strong, on-field performance.

Finally, all colleges should arrange their organizational charts so that the school's athletic director reports directly to the head of student affairs, rather than to the college provost or president. Creating this additional layer of oversight is valuable to improving the operation of college athletics in a number of ways. Most importantly, by having college athletic directors report to the head of student affairs, it aligns the process for evaluating college athletics departments

\footnotetext{
39 Tr. of Colum. U. \& Graduate Workers of Colum., Decision on Review and Order, Case No. 02RC-143012 (N.L.R.B. Aug. 23, 2016), http://apps.nlrb.gov/link/document.aspx/09031d45821c20d4 40 Joslyn P. DiRamio, The Role of Student Affairs Professionals within Intercollegiate Athletics Administration, 22 VT. ConNeCTION 1, 2 (2001).

${ }^{41}$ Id. at 6.
} 
with that of evaluating other student affairs departments. In addition, when college athletic directors report to the head of student affairs, it naturally leads athletic directors to adopt a more student-oriented approach to their jobs in the vein of other student affairs departments. Finally, a college athletics department in which the athletic director reports to the head of student affairs may even perceive itself as having less autonomy and thus a greater responsibility for helping to fulfill the college's overall mission.

\section{Conclusion}

At present, there is a dangerous disconnect at many U.S. colleges between the goals of their general student affairs department and the goals specifically of intercollegiate athletics. Although UNESCO, among others, recognizes that college athletics fall within the germane of student affairs, many U.S. colleges use their athletic programs to promote the brand name of their college rather than to support the learning, development, and success of student-athletes. Meanwhile, a small segment of colleges use their athletic programs as a way to generate substantial revenue streams that are then allocated as windfall payments to college administrators, athletic directors, and coaches. Consequently, the conduct of college athletic departments throughout the U.S. is misaligned with both UNESCO's general principles for student affairs, as well as UNESCO's eight sports-specific purposes/functions within higher education.

While the commercial/amateurism model of college sports is well-embedded in the American collegiate system, the current model presents a wide range of problems for college athletes, without yielding any clear, identifiable benefit. Thus, there seem to be two reasonable means to correct this anomaly. Some colleges reasonably should move to a true employee-athlete model of college sports that recognizes a certain number of their sports teams as "minor league" athletics rather than part of the traditional undergraduate experience. Meanwhile, most colleges should redesign their athletic programs to better conform to the general mission of their student affairs. Presumably, most colleges will choose the latter option.

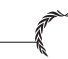

